Full-text Available Online at https://www.ajol.info/index.php/jasem http://ww.bioline.org.br/ja
J. Appl. Sci. Environ. Manage.

Vol. 25 (3) 407-414 March 2021

\title{
Design, Fabrication and Performance Study of Co-Pyrolysis System for Production of Liquid Fuel from Jatropha Cake with Polystyrene Waste
}

\author{
${ }^{* 1}$ BABAJO, SA; ${ }^{2}$ ENABUREKHAN, JS; ${ }^{2}$ RUFA'I, IA \\ ${ }^{* 1}$ Department of Mechanical Engineering, Modibbo Adama University, Yola, Nigeria \\ ${ }^{2}$ Department of Mechanical Engineering, Bayero University, Kano, Nigeria \\ *Corresponding Author Email: bbjosul@gmail.com, Tel: +2348034343083
}

\begin{abstract}
The increasing quantities of plastics and their disposal has been a major public concern. This paper therefore describes a fixed bed co-pyrolysis system designed and fabricated to obtain liquid fuel from a combination of Jatropha seed cake and polystyrene (plastic) waste using appropriate standard technique. The characterization of the feedstock materials (Jatropha cake and polystyrene) were carried out based on proximate and ultimate analysis. The products of the experiment were: liquid fuel, char and gas, while char and gas were considered as by-product. The parameters that were found to influence the product yields significantly includes: feed ratio, temperature and reaction time. The optimum liquid yield obtained from the co-pyrolysis of Jatropha cake with plastic (polystyrene) waste was $65.0 \mathrm{wt} \%$ (that is at the optimum parameters of feed ratio $1: 1$, temperature $500{ }^{\circ} \mathrm{C}$ and reaction time of 45 minutes). The liquid fuel obtained at these optimum conditions were analyzed based on physical and chemical properties, and compared to that of conventional diesel. The results of the liquid fuel obtained and conventional diesel in terms of viscosity, density and $\mathrm{pH}$ were $3.8 \mathrm{cP}, 3.5 \mathrm{cP}$, and $830 \mathrm{~kg} / \mathrm{m}^{3}, 853 \mathrm{~kg} / \mathrm{m}^{3}$, and 1.0, and neutral respectively. Elemental analyses of the liquid fuels from Jatropha cake with polystyrene waste showed that there is high contents of carbon and hydrogen, 87.2 and 8.3 respectively, which indicates that the liquid fuels may support combustion. The calorific value of liquid fuel from copyrolysis of Jatropha cake with polystyrene waste was $42.3 \mathrm{MJ} / \mathrm{Kg}$, and closer to that of conventional diesel $45.5 \mathrm{MJ} / \mathrm{Kg}$. Considering the results obtained from the study, the liquid fuel from Jatropha cake and polystyrene waste can be used as an alternative fuel.
\end{abstract}

DOI: https://dx.doi.org/10.4314/jasem.v25i3.15

Copyright: Copyright $(2021$ Babajo et al. This is an open access article distributed under the Creative Commons Attribution License (CCL), which permits unrestricted use, distribution, and reproduction in any medium, provided the original work is properly cited.

Dates: Received: 12 December 2020; Revised: 26 January 2021; Accepted: 12 February 2021

Keywords: Co-pyrolysis, Jatropha cake, Polystyrene waste, calorific value

There is a growing interest in producing fuel which can serve as an alternative to fossil fuel as a result of concerns arising from greenhouse gas emissions and consequent threat to human life (Tursunov. 2014). Generating fuel from other sources aside fossil resources can complement the nonrenewable fossil fuel reserves (Bulushev and Ross, 2011). Latest research focus is now on production of fuel from biomass. Presently, biofuels are produced from biomatter, mostly edible plant matter which serves as food for man using what was termed 'first generation' technologies; the use of which reduces man's food reserve (Ates et al., 2013).The decrease of fossil fuel resources such as coal, petroleum, and natural gas has encouraged research to develop new approaches to find or invent renewable fuel. One article has predicted that the coal reserves will be available until at least by the year 2112, and it will be the sole fossil fuel in the world after 2042 (Shafee and Topal, 2009; Babajo and Enaburekhan, 2019). Several efforts are currently underway to find alternative energy sources and develop technologies which have high efficiency and are environmentally- friendly. In this regard, most of the effort has been contributed by research into biomass energy. During the last three decades, more than half of the global research has been focused on biomass as renewable energy ( $56 \%$ ), followed by solar energy (26\%), wind power (11\%), geothermal energy (5\%), and hydropower (2\%) (Hossain et al., 2014). The high percentage of research into biomass energy can be supported by the availability of biomass resources which are the world's largest sustainable energy source and represent approximately 220 billion dry tons of annual primary production (Panda et. al., 2011;Babajo and Enaburekhan, 2019). Beside the effect of decreasing of fossil fuels, environmental concerns also play an important role in the development of renewable energy. Pyrolysis can be defined as a thermal decomposition of carbon based material in an oxygen deficient atmosphere using heat to produce syngas. No air or oxygen is present and no direct burning takes place. It takes place in temperature ranging from $400{ }^{\circ} \mathrm{C}-900{ }^{\circ} \mathrm{C}$. Conventional pyrolysis proceeds under a slow heating rate with solid, liquid and gaseous products in significant proportions (Satyendra et. al., 2013). It is 
an ancient process used mainly for charcoal production. Fast pyrolysis is associated with tar, at low temperature $(850 \mathrm{~K}-1250 \mathrm{~K})$ and/or gas at high temperature $(1050 \mathrm{~K}-1300 \mathrm{~K})$. At present the preferred technology is fast pyrolysis at high temperature with short residence time (Demirbas, 2009). Fast pyrolysis more accurately defined as thermolysis is a process in which a material such as biomass is rapidly heated to high temperatures in the absence of oxygen (Demirbas, 2009). Pyrolysis results in significant reduction in volume of waste (50 - 90\%) least in environmental problems compared to incineration and storable/transportable fuel or feed stock is obtained (Satyendra et. al., 2013). Pyrolysis has been identified as an efficient means of producing liquid fuel from municipal waste (Jeong et. al., 2006; Satyendra et. al., 2013; Sonawane et. al., 2015). It is a thermochemical conversion process that requires the application of heat in the temperature range of 250 $600{ }^{\circ} \mathrm{C}$ (Xiao et. al., 2010). Plastic materials have presently found wide applications and acceptance in the production of domestic household utensils, in automobile parts industry and several other manufacturing processes (UNEP, 2010). The huge quantities of these plastic products will definitely end up in waste dump sites due to their non-biodegradable in nature, thus increasing the quantity of solid waste generated globally (Panda and Singh, 2011). Waste management and utilization has been a global concern and as such with the current global focus on conversion of waste to useful energy resources (wtE), there is a concerted call to look for efficient and effective ways of converting these wastes into useful energy resources (Satyendra et. al., 2013). The plate 1 and 2 below shows the jatropha cake and polystyrene waste respectively.

\section{MATERIALS AND METHODS}

Materials: The materials used in this study includes; Jatropha Curcas Seed Cake: Jatropha curcas seed cake was selected for this study. It was obtained at Technology Business Incubation Center (TBIC), Kano, in Kano state. It was used as one of the feed stock in this research.

i. Plastic Waste: Polystyrene was selected as the plastic material in this study. Polystyrene waste was obtained from a local rubbish collection point. The polystyrene was sun dried for several days.

ii. Thermocouple: A thermocouple is a sensor used to measure temperature. The thermocouple is a sensing device which detects the temperature produced by the electric heater. The thermocouple that was used for this research was for measuring the temperature in the reactor. The thermocouple consists of a wire which was placed in the reactor in order to detect the temperature inside the reactor.

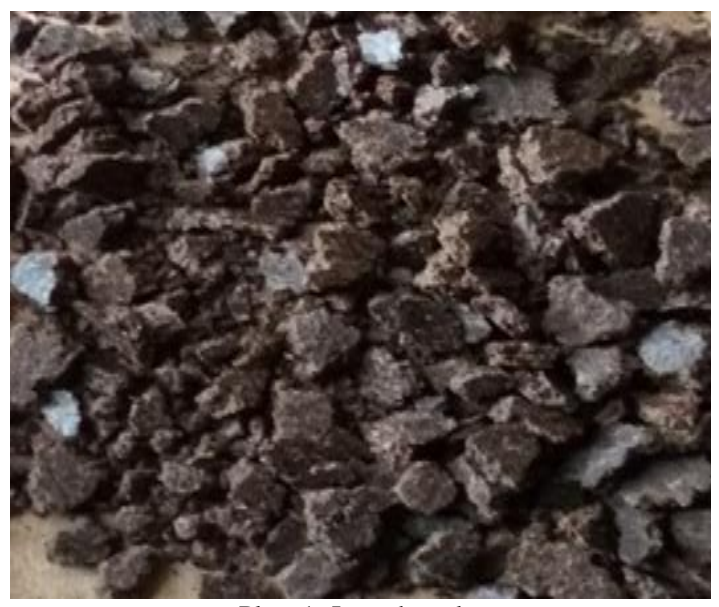

Plate 1: Jatropha cake

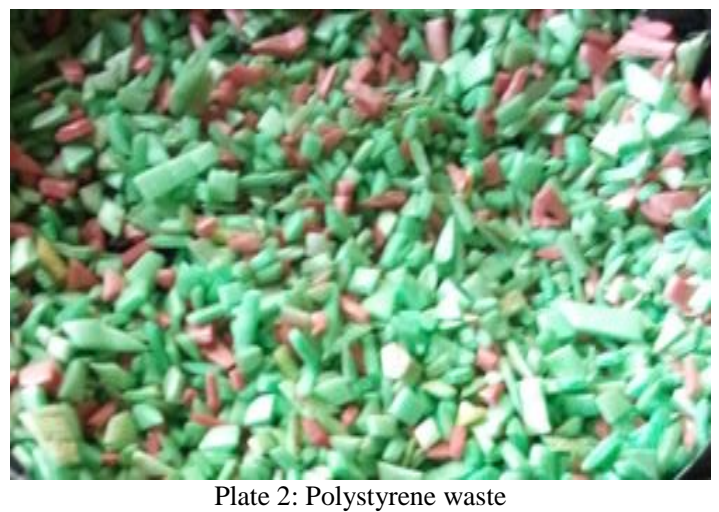

iii. Temperature Controller: A temperature controller is a device that controls the temperature of the electric heater. It was used for controlling the temperature inside the reactor.

iv. Test Sieves: The test sieve that was used for this study was a standard sieve that will sieve the particle of the material or feed stock of not more than $2 \mathrm{~mm}$. It was used for sieving the feed stocks to a desired particle size.

v. Weight Balance: This is a device to measure weight. The type of weight balance that was used for this study was Digital of (SF - 400, capacity $7000 \mathrm{~g} * 1 \mathrm{~g} / 280 \mathrm{ozx} 0.1 \mathrm{oz})$ model. It was used for determining the weight of the material or feedstock.

vi. Stop Watch: The type of stop watch that was used for this research was Digital Stop watch of N1280 model. The stop watch was used for measuring the time that will take a material or a feed stock to pyrolyze.

vii. Viscometer: The type of viscometer that was used for this study is Brookfield viscometer with RBT - 43320 model. The viscometer was used for measuring the viscosity of the fuel.

viii. Bomb Calorimeter: The type of calorimeter that was used for this study is bomb calorimeter with 
A1329BD model. The bomb calorimeter was used for determining the calorific value of the fuel.

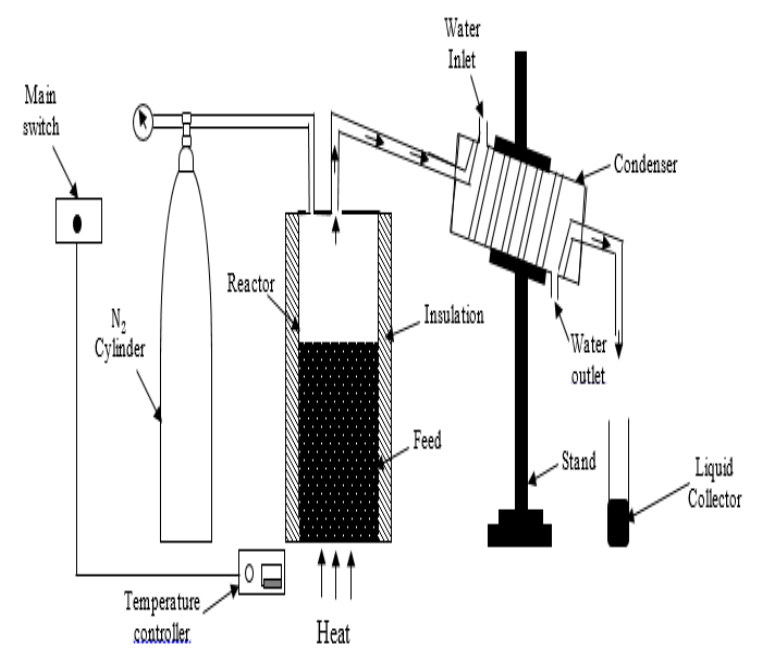

Fig 1: Conceptual Representation of Pyrolysis System

Methods: Jatropha seed cake and polystyrene (plastic) waste were sorted, sun dried and shredded into smaller size. Proximate and ultimate analysis of a sample of the prepared feedstock was undertaken based on American Standard Test Methods (ASTM).

Design and Fabrication of the Co-pyrolysis Reactor: Pyrolysis is the thermal decomposition of materials at elevated temperatures in an inert atmosphere. There are three byproducts of pyrolysis process which includes; liquid, gas and char. The main objective of this pyrolysis process is to produce liquid fuel. The main components of the pyrolysis reactor are the reactor and the condenser. The figure 1 below shows the conceptual representation of the pyrolysis system

Design of the Pyrolysis Reactor:-The main part of the co-pyrolysis system are reactor and the condenser. Vapour residence time $\left(t_{\mathrm{v}}\right)$ in reactor is an important parameter to achieve maximum yield of liquid. The apparent vapor residence time usually less than 5 seconds for fast pyrolysis otherwise secondary cracking of vapour product would occur resulting in higher amount of gases and lower amount of liquid production (Babajo et al., 2019). The pyrolysis reactor will be designed based on the following considerations;

- $\quad$ Pyrolysis temperature range of 450 to $550^{\circ} \mathrm{C}$.

- $\quad$ Particle size of $\leq 2 \mathrm{~mm}$

- $\quad$ Reaction time of 30 minutes

- $\quad$ Reactor thickness of $4 \mathrm{~mm}$.
The figure 2 below shows the conceptual representation of the reactor

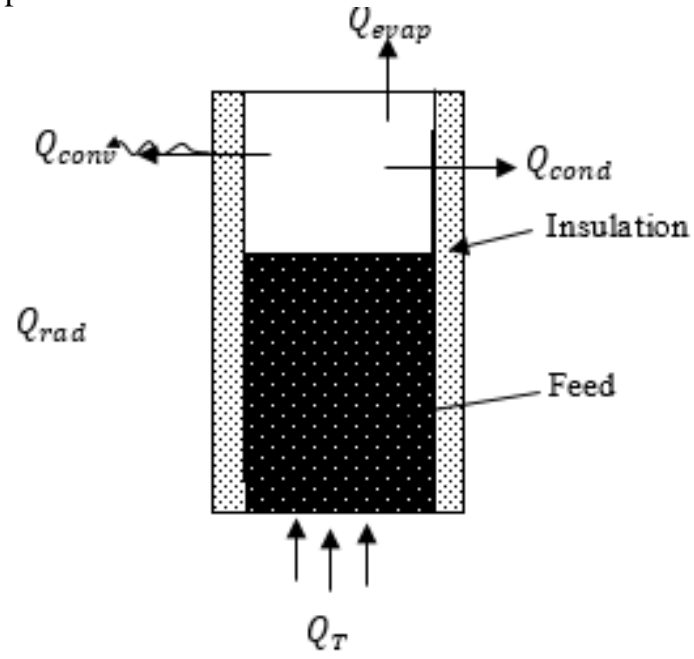

Fig 2: Conceptual Representation of the Reactor

Refer to figure 2 above. The energy required to heat up the system is given by the following equation;

$$
Q_{T}=Q_{c o n d}+Q_{c o n v}+Q_{\text {rad }}+Q_{\text {eva }} \quad \ldots
$$

Where:

$Q_{T}$ is the Total heat required to raise the temperature of the feedst temperature,

$Q_{\text {cond }}=$ heat loss through conduction,

$Q_{\text {conv }}$ heat loss through convection, $\quad Q_{\text {rad }}=$ heat loss through radiattion and $Q_{\text {eva }}=$ heat loss through evaporation.

$$
\begin{aligned}
Q_{\text {cond }}=\frac{13.389 \times 0.181584 \times(723-303)}{0.05} & =20422.32 \mathrm{~W}
\end{aligned}
$$

Heat loss through convection is given by

$$
\begin{aligned}
Q_{\text {conv }}= & h A\left(T_{1}-T_{\infty}\right) \\
Q_{\text {conv }}= & 6.67 \times 0.181584(30-26) \\
& Q_{\text {conv }}=4.8425 \mathrm{~W}
\end{aligned}
$$

Heat loss thorough convection $=4.842 \mathrm{~W}$

Heat loss through radiation is given by

$$
\begin{gathered}
Q_{r}=\varepsilon \sigma A \mathrm{~T}_{\mathrm{i}}^{4} \quad \cdots \\
Q_{r}=0.85 \times 5.67 \times 10^{-8}\left\{(303)^{4}-(298)^{4}\right\} \\
Q_{r}=4.75 \mathrm{~W}
\end{gathered}
$$

Heat produced by the gas

$$
Q_{g}=\frac{\rho \times v \times h_{g}}{t} \quad \ldots
$$


$\rho=$ density of the gas at $450^{\circ} \mathrm{C}$

$$
=\frac{0.007611 \mathrm{~kg}}{\mathrm{~m}^{3}}
$$

$h_{g}=$ latent heat of vaporization at $450^{\circ} \mathrm{C}$

$$
=3381.6 \times \frac{10^{3} \mathrm{~J}}{\mathrm{~kg}}
$$

$\mathrm{T}=30$ minutes (time required for materials to pyrolyzed) and

$$
\begin{gathered}
v=\text { volume of the gas }=0.00245138 \mathrm{~m}^{3} \\
Q_{g}=\frac{0.007611 \times 0.00245138 \times 3381.6 \times 10^{3}}{1800} \\
Q_{g}=0.03505 \mathrm{~W} \\
Q_{T}=20422.32+4.8425+4.75+0.03505 \\
Q_{T}=20431.95 \mathrm{~W}
\end{gathered}
$$

Insulation:_The reactor was fully lagged with a very good lagging material (fiberglass) to minimize heat loss to the surrounding and increase the utilization of the steam generated. The correct thickness of the lagging material used for this design was $5 \mathrm{~cm}$ thick. This is because, as thickness of lagging increases, the resistance to heat transfer by thermal conduction also increases (Sinnoth, 1999). The figure 3 below shows the insulator of the reactor.

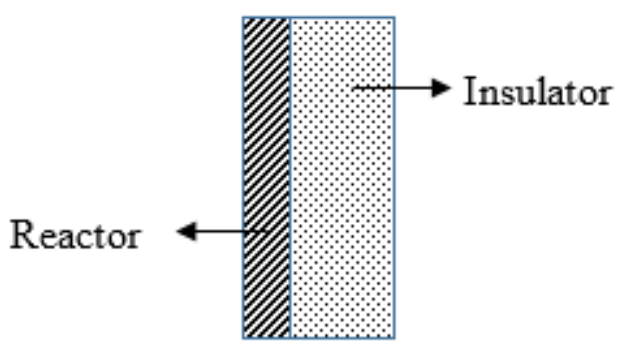

Fig 3: Insulator of the Reactor

Heat loss through conduction is given by the following relation

$$
\begin{gathered}
Q_{\text {cond }}=\frac{K A\left(T_{1}-T_{2}\right)}{\Delta x} \ldots \\
Q_{\text {cond }} \ldots \\
=\frac{13.389 \times 0.181584 \times(723-303)}{0.05} \\
Q_{\text {cond }}=20422.32 \mathrm{~W}
\end{gathered}
$$

Design of the Condenser:_Condenser otherwise heat exchanger is a device that facilitates heat transfer between two or more fluids at different temperatures (Rajput, 2005). In this design, the condenser is to be used to condense the vapour (which is a mixture of feed stock materials) that will be coming from the reactor. The design procedure used for the condenser design is as illustrated by Singhe (2011). The condenser was designed based on the following considerations;

- The internal diameter of the copper tube is $14 \mathrm{~mm}$.

- The outer diameter of the copper tube is $16 \mathrm{~mm}$.

- $\quad$ The length of the condenser is $340 \mathrm{~mm}$

- $\quad$ The width of the condenser is $140 \mathrm{~mm}$.

The figure 3 below shows the conceptual representation of the condenser is as shown in figure 2 below.

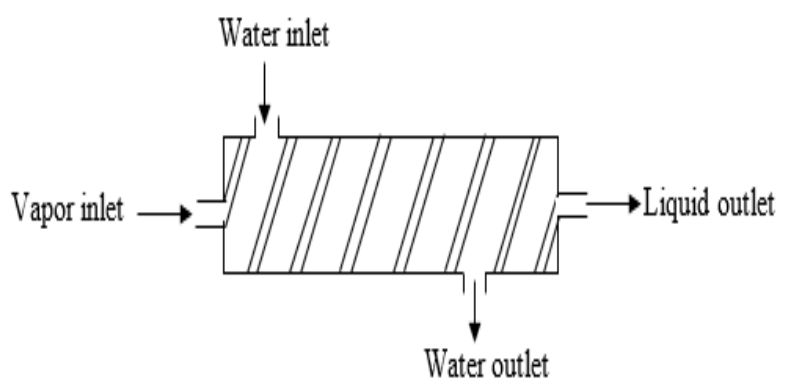

Fig 4: Conceptual Representation of Condenser

the heat loss by condensing vapour $=$ heat gained by the cooling water Volume of the reactor $=$

$0.008171282 \mathrm{~m}^{3}$

volume of the gas $=$

$30 \%$ of the volume of the reactor

$\begin{aligned} \frac{30}{100} & \times 0.008171282=0.00245138 m^{3} \\ Q_{g} & =\rho \times v \times h_{g}\end{aligned}$

$=\frac{0.007611 \times 0.00245138 \times 3381.6 \times 10^{3}}{1800}$

$$
Q_{g}=0.03505 W
$$

Heat produced by the gas is $0.03505 \mathrm{~W}$ heat loss by condensing vapour $=$ heat gain by the cooling water

$$
\begin{gathered}
Q_{g}=m h_{g}=m_{w} c_{w}\left(T_{\text {out }}-T_{\text {in }}\right) \\
Q_{g}=m_{w} c_{w}\left(T_{\text {out }}-T_{\text {in }}\right)
\end{gathered}
$$

By substituting from equation 2.7 


$$
\begin{aligned}
& 63.092=5.2 \times 4.2\left(T_{\text {out }}-20\right) \quad T_{\text {out }}= \\
& 22.88^{\circ} \mathrm{C} \approx 23^{\circ} \mathrm{C}
\end{aligned}
$$

The temperature at the outlet $\approx 23^{\circ} \mathrm{C}$.

The length of the tube is given by the following formula;

$$
\begin{gathered}
L=\frac{m_{w} c_{w}\left(T_{o u t}-T_{\text {in }}\right)}{\pi d^{2} \rho h_{g}} \\
L=\frac{5.2 \times 4.2 \times(23-20)}{\left(\pi \times 0.014^{2} \times 0.007611 \times 3381600\right)} \\
L=0.041 \mathrm{~m} \approx 410 \mathrm{~mm} .
\end{gathered}
$$

The length of the tube can be determined by the use of the following relations;

$$
L=\pi D N \quad \cdots
$$

Where: $\mathrm{L}=$ the length of the tube? $\mathrm{N}=$ number of turns and diameter $\mathrm{D}=$ diameter of the tube $14 \mathrm{~mm}=$ $0.014 \mathrm{~m}$,

$$
N=\frac{0.41}{\pi \times 0.014} \approx 10 \text { turns }
$$

Assembly of the Co-pyrolysis Unit:_Assembly of the various components of co-pyrolysis unit is the most important task for better performance of the plant. At first, the fixed bed reactor's lid (on which connecting was welded for easy handling) was bolted (with airtight cover gasket) to prevent emission of gases to the atmosphere and air entrance) to the reactor. The connecting pipe was extended to the condensing unit with the help of clips at both ends. The reactor was placed on the electrical furnace to supply heat uniformly. A hollow cylinder lined with lagging material (in which the reactor was placed) was used to prevent heat to loss to the atmosphere. Figure 3.3 depicts the co-pyrolysis system.

Experimental Procedure: The pyrolysis set up consists of a reactor furnace system, which is made of stainless steel (SS) materials sealed at one end and with an outlet tube at other end, in which the furnace temperature was maintained constant using a PID controller. At the outlet of reactor, a condenser was attached to condense the vapours coming out of it. The condensed oil was collected in a collecting jar at the end of condenser. Dried and weighted Jatropha curcas seed cake with plastic (polystyrene) waste of (1:1) of particle size of $1.5 \mathrm{~mm}$ was fed into the fixed bed reactor for pyrolysis.

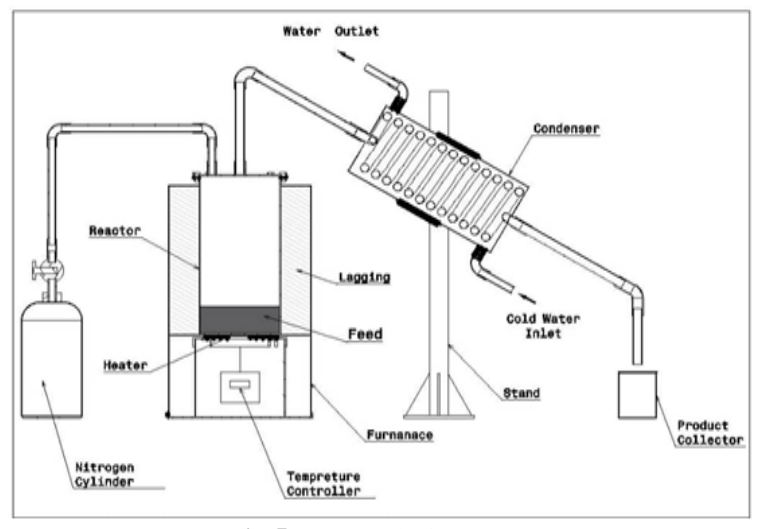

Fig 5: Co-pyrolysis System

The sample was taken in the stainless steel reactor for each run and placed in an electrically heated furnace. Pyrolysis experiments were carried out at different temperatures of $450{ }^{\circ} \mathrm{C}, 500{ }^{\circ} \mathrm{C}$ and $550{ }^{\circ} \mathrm{C}$ with a heating rate of $20^{\circ} \mathrm{C} \mathrm{min} \mathrm{min}^{-1}$ and maintained till the reaction completes which is 30 minutes. A nitrogen flow rate of $2 \mathrm{~L} / \mathrm{min}$ was employed in other to purge air out of the system which prevent it from secondary cracking. The volatiles from the reactor were condensed in a water cooled condenser and the noncondensable gases were flared into the atmosphere. The condensed oil was collected in a liquid collector, and weighted. The remaining residue (char) was also collected and weighted after cooling the reactor. The weight of non-condensable gases was measured by applying mass difference. All experiments were performed thrice and the average values were reported. The liquid fuel yield was collected after it was condensed and was recorded carefully kept (separately) in well-sealed containers under room temperature. This procedure was repeated for the following feed ratios of 1:2 and 1:3 (i.e Jatropha cake with plastic waste) and the temperatures of $500{ }^{\circ} \mathrm{C}$ and $550{ }^{\circ} \mathrm{C}$, with the reaction time of 45 and 60 minutes.

Determination of Physicochemical properties of the liquid fuel obtained from co-pyrolysis of Jatropha cake with polystyrene waste: The chemical and physical properties of the liquid fuel in terms of the density, viscosity, $\mathrm{pH}$ value, carbon, hydrogen, nitrogen, oxygen, sulphur, water content and calorific value were determined based on American Standard Test Method (ASTM).

\section{RESULTS AND DISCUSSION}

The proximate and ultimate analysis of Jatropha seed cake are presented in Table 1. The proximate analysis shows that the sample (Jatropha cake) had high concentration of volatile matter $(78.30 \%)$. 
The inherent moisture content of the sample was $0.76 \%$. The ash and fixed carbon content contains $1.8 \%$ and $20.94 \%$ respectively. Ultimate analysis data (Table 1) indicates that the sample contains high proportion of carbon of $57.20 \%$, with relatively low concentrations of sulphur $(0.5 \%)$, nitrogen $(6.10 \%)$, and hydrogen $(8.30 \%)$.

The oxygen content of the sample was found by calculation $(27.90 \%)$. The calorific value or energy content of the sample was determined to be 25.47 $\mathrm{MJ} / \mathrm{kg}$.

Table 1: Proximate and Ultimate Analysis of Jatropha Cake

\begin{tabular}{ll}
\hline \multicolumn{2}{l}{ Proximate Analysis (\% wt) } \\
\hline Moisture content & 0.76 \\
Volatile matter & 78.30 \\
Ash content & 1.80 \\
Fixed Carbon & 20.94 \\
\hline Ultimate Analysis (\% wt) \\
\hline Carbon & 57.20 \\
Hydrogen & 8.30 \\
Nitrogen & 6.10 \\
Sulphur & 0.50 \\
Oxygen & 27.90 \\
Calorific value $(\mathrm{MJ} / \mathrm{Kg})$ & 25.47 \\
\hline
\end{tabular}

Table 2: Proximate and Ultimate Analysis of (Plastic) Polystyrene Waste

\begin{tabular}{ll}
\hline \multicolumn{2}{l}{ Proximate Analysis (\% wt) } \\
\hline Moisture content & 0.21 \\
Volatile matter & 99.30 \\
Ash content & 0.00 \\
Fixed Carbon & 0.59 \\
\hline \multicolumn{2}{l}{ Ultimate Analysis (\% wt) } \\
\hline Carbon & 89.10 \\
Hydrogen & 8.02 \\
Nitrogen & 0.22 \\
Sulphur & 0.01 \\
Oxygen & 2.65 \\
\hline
\end{tabular}

\begin{tabular}{ll}
\hline Calorific value $(\mathrm{MJ} / \mathrm{Kg})$ & 41.13 \\
\hline
\end{tabular}

Proximate analysis (Table 2) shows that the sample (polystyrene waste) had high concentration of volatile matter $(99.30 \%)$. The inherent moisture content of the polystyrene waste was $0.21 \%$, however the sample doesn't contain ash content. The fixed carbon obtained from the sample was $0.59 \%$

Ultimate analysis data (Table 2) indicates that the polystyrene waste contains high proportion of carbon of $89.10 \%$, with relatively low concentrations of sulphur $(0.01 \%)$, nitrogen $(0.22 \%)$, and hydrogen $(8.02 \%)$. The oxygen content of the polystyrene waste was found by calculation $(2.65 \%)$. The calorific value or energy content of the sample was determined to be $41.13 \mathrm{MJ} / \mathrm{kg}$. The Table 3 depicts the results of liquid fuel produced through co-pyrolysis of Jatropha cake with plastic waste operating under various conditions using the Taguchi experimental design. It can be observed that from figure 1 above, as the feed ratio of the samples increases the liquid yield also increases, and the liquid fuel yield was optimum at the feed ratio of $1: 1$. More so, the reaction temperature and reaction time that produces high liquid fuel yield was at $500{ }^{\circ} \mathrm{C}$ and 45 minutes respectively. So the optimum parameters that can yield high liquid fuel was at a feed ratio of $1: 1$, reaction temperature of $500{ }^{\circ} \mathrm{C}$ and reaction time of 45 minutes. The result (liquid fuel) obtained at that conditions was $66.0 \mathrm{wt} \%$. The Table 4 depicts the physical and chemical properties of the optimized liquid fuel from the co-pyrolysis of Jatropha cake with (plastic) polystyrene waste.

Table 3: Co-pyrolysis of Jatropha cake with polystyrene waste

\begin{tabular}{|c|c|c|c|c|}
\hline \multirow{2}{*}{$\begin{array}{l}\text { Experiment } \\
\text { Number }\end{array}$} & \multicolumn{3}{|c|}{ Levels } & \multirow{2}{*}{$\begin{array}{l}\text { Liquid } \\
\text { Fuel } \\
\text { (wt. \%) }\end{array}$} \\
\hline & $\begin{array}{l}\text { Feed } \\
\text { Ratio }\end{array}$ & $\begin{array}{l}\text { Temperature } \\
\left({ }^{\circ} \mathrm{C}\right)\end{array}$ & $\begin{array}{l}\text { Reaction } \\
\text { Time (Min) }\end{array}$ & \\
\hline 1 & $1: 1$ & 450 & 30 & 60.8 \\
\hline 2 & $1: 1$ & 500 & 45 & 65.0 \\
\hline 3 & $1: 1$ & 550 & 60 & 57.3 \\
\hline 4 & $1: 2$ & 450 & 45 & 59.5 \\
\hline 5 & $1: 2$ & 500 & 60 & 60.7 \\
\hline 6 & $1: 2$ & 550 & 30 & 55.0 \\
\hline 7 & $1: 3$ & 450 & 60 & 53.7 \\
\hline 8 & $1: 3$ & 500 & 30 & 54.0 \\
\hline 9 & $1: 3$ & 550 & 45 & 51.2 \\
\hline
\end{tabular}




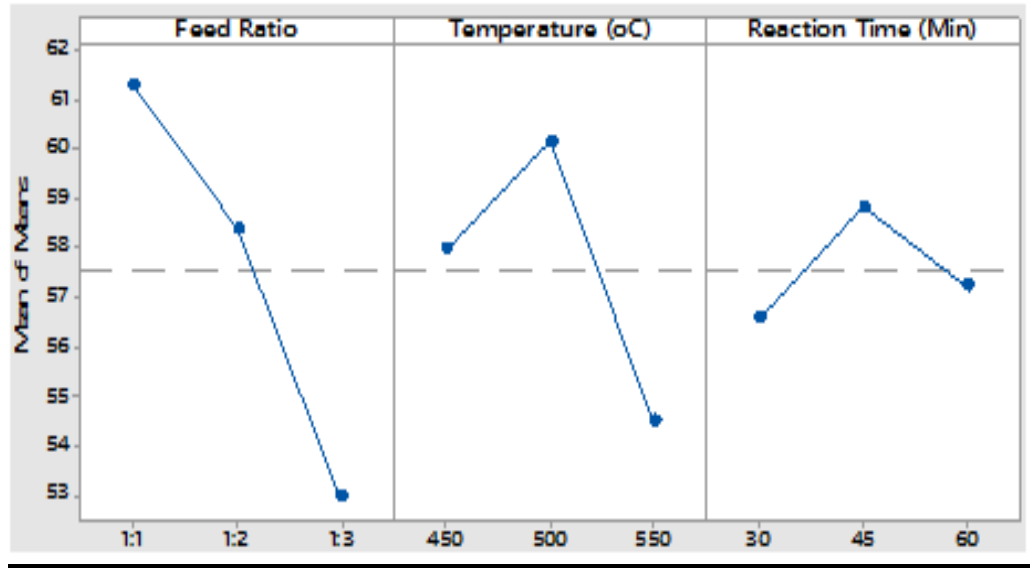

Fig 1: The graph of mean of means versus feed ratio, temperature and Reaction Time Table 4: Physical and chemical Properties of Liquid fuel from Co - Pyrolysis of Jatropha Cake with Polystyrene

\begin{tabular}{llll}
\hline Properties & \multicolumn{3}{c}{ Parameters } \\
\cline { 2 - 4 } & $\begin{array}{l}\text { Jatropha Cake } \\
\text { with Polystyrene }\end{array}$ & Diesel & Unit \\
\hline Viscosity & 3.8 & 3.5 & $\mathrm{Cp}$ \\
PH & 1.0 & - & - \\
Density & 830 & 853 & $\mathrm{Kg} / \mathrm{m}^{3}$ \\
Elemental Composition & & & \\
Carbon & 85.3 & 86.6 & $\mathrm{wt} \%$ \\
Hydrogen & 8.3 & 13.1 & $\mathrm{wt} \%$ \\
Nitrogen & 0.41 & 0.04 & $\mathrm{wt} \%$ \\
$\begin{array}{l}\text { Oxygen (by } \\
\text { difference) }\end{array}$ & 5.79 & 1.8 & $\mathrm{wt} \%$ \\
Sulphur & & & \\
Water Content & 0.2 & 0.11 & $\mathrm{wt} \%$ \\
Calorific Value & 0.4 & $<0.1$ & $\mathrm{wt} \%$ \\
& 42.3 & 45.5 & $(\mathrm{MJ} / \mathrm{Kg})$ \\
\hline
\end{tabular}

Optimization process for the co-pyrolysis of Jatropha cake with polystrene waste: The figure 1 below shows the results of the optimization process for the copyrolysis of Jatropha cake with plastic waste. It can be seen from Table 4 that liquid fuel from Jatropha cake with plastic, had viscosity of $3.8 \mathrm{cP}$, PH of 1.0 and density of $830 \mathrm{~kg} / \mathrm{m}^{3}$ respectively. The elemental analysis was carried out on the liquid fuel obtained from co-pyrolysis of Jatropha cake with (plastic) polystyrene waste to identify the presence of various elements. It was noticed that, the liquid fuel obtained from Jatropha cake with polystyrene waste contained 85.3 wt. $\%, 8.3$ wt. $\%, 0.41$ wt. $\%, 5.69$ wt. $\%$ and $0.3 \%$ by weight of Carbon, Hydrogen, Nitrogen, Oxygen and Sulphur respectively. The elemental compositions of the liquid fuel were closer to that of conventional diesel. The water content of the Jatropha cake with (Plastic) polystyrene waste was 0.4 and that of conventional diesel was less than 0.1 . The calorific value of the Jatropha cake with (Plastic) polystyrene waste was $42.3 \mathrm{MJ} / \mathrm{Kg}$, while that of conventional diesel is $45.5 \mathrm{MJ} / \mathrm{Kg}$.

Conclusion: The findings of the characterization study using proximate and ultimate analysis indicated that, the Jatropha cake and (plastic) polystyrene waste has a potential source of liquid fuel production. The liquid yield obtained from the co-pyrolysis of Jatropha cake with polystyrene waste was $65.2 \mathrm{wt} \%$. The physical and chemical properties of the optimized liquid fuel produced via co-pyrolysis of Jatropha cake with plastic (polystyrene) waste showed results closer to that of conventional diesel. Therefore, it can be used as an alternative to fuel.

\section{REFERENCES}

Ates, F; Norbert, M; Nikolett, B (2013) Comparison of real waste (MSW and MPW) pyrolysis in batch reactor over diferent catalysts. Part I: product yields, gas and pyrolysis oil properties. Biores Technol 133: 443-454

Babajo, S. A, Enaburekhan, J. S (2019). PhysioChemical Properties of Jatropha biodiesel kerosene blends Used as Fuel in Pressurized Kerosene Cooking Stove. Bayero Journal of Engineering and Technology (BJET) Vol.14 NO.1 February, 2019. ISSN: 2449-0539.

Babajo, S.A, Enaburekhan, J. S. Rufai, I. A (2019) A Review On Co-Pyrolysis of Biomass with Plastic Waste: An Optional Technique to Produce A High Grade Pyrolysis Oil. Bayero Journal of 
Engineering and Technology (BJET) Vol.14 NO.1 February, 2019. ISSN: 2449-0539.

Babajo, S. A, Enaburekhan, J. S. (2019). Emission Characteristics of Jatropha biodiesel - kerosene blends Used as Fuel in Pressurized Kerosene Cooking Stove. Bayero Journal of Engineering and Technology (BJET) Vol.14 NO.2 August, 2019. ISSN: 2449-0539.

Bulushev, D A; Ross, J.R (2011) Catalysis for conversion of biomass to fuels via pyrolysis and gasification: a review. Catal Today 171: 1-13.

Demirbas, A (2009). An overview of biomass pyrolysis. Ener. Sources 24(5). 471-482.

Hossain, A; Hassan, M.R; Islam M. R (2014). Design fabrication and performance study of a biomass solid waste pyrolysis system for alternative liquid fuel production. Global J. Reserve Eng. 14 (5).

Jeong, B.H; NaJ, G; SeongSoo, K (2006) Pyrolysis of low density polyethylene using sunthetic catalyst produced from fy ash. J Mater Cycles Waste Manage 8:126-132.

Panda, A K; Singh R.K (2011) Catalytic performances of kaoline and silica alumina in the thermal degradation of polypropylene. J Fuel Chem Technol 39(3): 198-202.

Panda, A. K; Singh, R.K; Mishra, D.K (2011) Thermolysis of waste plastics to liquid fuel: a suitable method for plastic waste management and manufacture of value added products -a world prospective. Renew Sustain Energy Rev 14(1):233-248.
Satyendra, S.T; Krishna, K.K; Suresh, PS (2013) Low cost catalyst synthesized from coal flyash for regaining liquid fuel from HDPE and its kinetic analysis. Int J Chem Petrochem Technol (IJCPT) 3(2):31-40.

Shafee, S; Topal E (2009). When will fossil fuel reserve be diminished? Energy Policy 37(1) 181189.

Sonawane, Y; Shindikar M; Khaladkar, M (2015) Use of catalyst in pyrolysis of polypropylene waste into liquid fuel. Int Res J Environ Sci 4(7):24-28.

Tursunov, O (2014) A comparison of catalysts zeolite and calcined dolomite for gas production from pyrolysis of municipal solid waste (MSW). Ecol Eng 69:237-243.

UNEP (2010) Training module for the assesment of plastic waste. International Environmental Technology Centre, Osaka

Xiao, X; Le, D; Li, L; Meng, X.C; Morishita, K; Takarada, T (2010) Catalytic steam gasification of biomass in fuidized bed at low temperature: conversion from livestock manure compost to hydrogen-reach syngas. Biomass Bioenergy 34:1505-1512 